\title{
Development of Jawi Spelling Skills Applications, 'Oh Jawiku'
}

https://doi.org/10.3991/ijim.v13i07.10759

\author{
Noor Asmina Binti Mohd Rashid ( ${ }^{\bowtie}$, Shaharuddin Bin Md Salleh, \\ Norah Binti Md Noor \\ Universiti Teknologi Malaysia, Johor, Malaysia \\ noorasmina@gmail.com
}

\begin{abstract}
In the past, Jawi script was the main medium of intermediation in Malaya. However, since the emergence of the Roman script, the use of Jawi script has been marginalized causing less awareness among some of the younger generation on the uniqueness of Jawi script. Therefore, 'Oh Jawiku' mobile application has been developed to attracting students to explore Jawi script especially the spelling of Jawi words. This 'Oh Jawiku' mobile application used constructivism approach and ADDIE model during the development process. This study used quantitative one group pre-test and post-test research design that conducted among 20 students of a primary school. The result shows that the mean value of the post-test was higher than the pre-test which is 89.00 while the percentage of students who liked the 'Oh Jawiku' application was high. In conclusion, the application of mobile games 'Oh Jawiku' able to attract students to learn Jawi indirectly raised the dignity of Jawi script in the future besides supporting the 21 st- century education.
\end{abstract}

Keywords—Jawi Script, Mobile Applications, Game based learning, Spelling Methods, Student's Attraction

\section{$1 \quad$ Introduction}

In the past, Jawi script plays an important role in society as an important intermediary in all matters such as the administration of government, diplomatic relations between the state of affairs, Malay customs, trade, and also in the education system [1]. However, since the Roman script introduced in Malaya, most businesses have been using the Roman script for official purposes and Jawi script is given emphasis on matters related to Islam only. The uniqueness of Jawi has been forgotten by the younger generation nowadays even some of them do not know how to write in Jawi and others do not recognize the letters in Jawi [2].

The objective of this study is to develop Jawi spell-playing game applications based on constructivist theory. Besides that, this study also to identify the effect of 'Oh Jawiku' mobile applications towards year two primary school students in Jawi learning. The mobile application was also built to inculcate students' interest in Jawi writing so Jawi writing is not forgotten by the younger generation. 


\subsection{Background of the problem}

This study has been conducted based on the support from the observations made based on previous studies.

The Problem of Learning Jawi Script among School Students: The education system in Malaysia which emphasizes the use of Roman script directly diminishes the use of Jawi script because the Jawi's writing is used only in Islamic Education subjects [3]. Not only that, the problem is also due to the fact that the Malays themselves do not apply the use of Jawi in their lives [4].

According to [3], the Jawi script gradually marginalized and disliked as most of the today's youth are 'buta Jawi'. Among the factors that school students cannot master Jawi writing today is the problem of less skillful teachers using Jawi writing while teaching. According to observations by [5], many Islamic Education subject teachers use the Roman script as a teaching medium to achieve teaching objectives.

According to [3], in his study stated in the past, most books or religious books are written and printed using Jawi script but now most of the books or religious books used in schools are written using Roman script that causes students to lack resources in reinforcing mastery of Jawi. To further enhance Jawi writing among the younger generation, especially the students, teaching methods by teachers need to be improved so as to attract students to explore the Jawi script as adding creative features of the innovation in the teaching method [6] and [5].

In addition, teaching methods delivered by teachers also lead to students' level of control and interest in Jawi Education. According to the study conducted by [6], the teaching method used by Islamic Education teachers cannot help students to master Jawi learning because teachers have no special skills in Jawi teaching as well as the teaching and learning process is teacher-centered and does not focus on students' understanding. This is supported by a study conducted by [5] where students' understanding and interest in Jawi Education has proven to increase as teachers use different and more creative methods during the teaching process.

The Effectiveness of Mobile Application Use in Teaching and Learning Systems: According to [7], the use of mobile devices in the education sector provides students with the ability to share information while conducting group work in line with online learning or better known as m-learning. In addition, [8] also stated in their study that mobile-based learning or m-learning learning is a self-directed learning process where learning can take place everywhere and not just in the classroom.

Among the advantages of the mobile application that described by [9] is that it is easy to use by students as most of the menu and directions available in mobile phones are user-friendly. Additionally, it also helps students not to feel embarrassed when learning because of online learning conceptually 'alone'. This can help students to continue sharing ideas without having to deal with everyone and they can make them more aggressive when studying.

Jawi Learning Approach through Multimedia Applications: An innovative approach has to be incorporated into the teaching and learning method of Jawi to attract students to continue learning Jawi. The study conducted by [10] shows that students 
need something interesting and interactive to stimulate their minds while studying Jawi. This is also can avoid students to get bored in the class.

The results of the study by [11] found that users or students are more interested in using multimedia technology as Jawi learning medium. The response from users can be concluded that the use of such applications plays an important role in the education system including Jawi education. In addition, the Jawi multimedia application needs to be designed more creatively to attract users.

So, the mobile application is selected to help resolve problems in learning Jawi scripts due to its ability to attract students and due to more affordable technology and improving digital networks, many people turn to mobile devices as their first choice for connectivity. In addition, the game elements by [12] is used in this app development such as play, fun, interactive, levels, direction, challenge, adaptive, successful, results, and video to make the application more interactive. According to[13], game based-learning will help the student to the deep understanding about something that they learn because they will have their own chance to explore and study about something when playing.

\section{$2 \quad$ Methodology}

The ADDIE model is used as an instructional design to help in the development process of 'Oh Jawiku' mobile applications. Five phase of the development process which is analyzed, design, develop, implement, and evaluation. Each phase of the process conducted based on the respondent criteria that are year two of primary school.

\subsection{Analysis phase}

In the analysis phase, the problems need to identify and solved to set the objectives in the study. After that, the factors or causes of the problem that involve the aspects of the user or the student, the learning environment, and the teaching objectives need to be identified besides analyzing learning theories, determine content, and determine learning objectives.

This mobile learning application used constructivism and game-based learning approach. Constructivism learning theory is referred to the active and dynamic learning among students where they will be more creative in solving the problem and makes them more aggressive while thinking besides adapting the new knowledge from the constructivism learning approach [14].

Each student will go through this constructivism learning theory where they can build ideas and knowledge with their own efforts and not with the help of others. In addition, this method helps students to explore and aggressively think about problemsolving. Students will have their own instincts by linking existing information in their minds to new ideas to be useful information [14]. Through the research conducted, the 'Oh Jawiku' app will enhance the student's effort in developing ideas to answer the 
questions provided in the app. In this study, all constructive theoretical elements are adapted in the app.

Game-based learning can help students develop brain thinking and language skills [15]. In addition, through the method of play, learning becomes more fun and challenging as students gain a high-level thinking process. There are ten game elements adapted from game elements [12] into 'Oh Jawiku' application that will be developed like play, fun, interactive, level, command, challenging, adaptive, success, result, and video. The combination of these elements can generate a game app that can attract users.

\subsection{Design phase}

After all the analysis phase, the second phase will be carried out the design phase. Through this phase, the process of designing mobile game applications will be carried out as well as explaining the four main elements:

- Information Design

- Interaction Design

- Presentation Design/Interface

- Application Flowchart Design

Each process carried out in this second phase will have a relationship with each other to ensure that the process is not dropped. Additionally, the quality of work needs to be ensured performed will meet the needs of end users as well as the stated objectives. In addition, each design will be applied through the process of designing mobile game applications using constructivism learning theories.

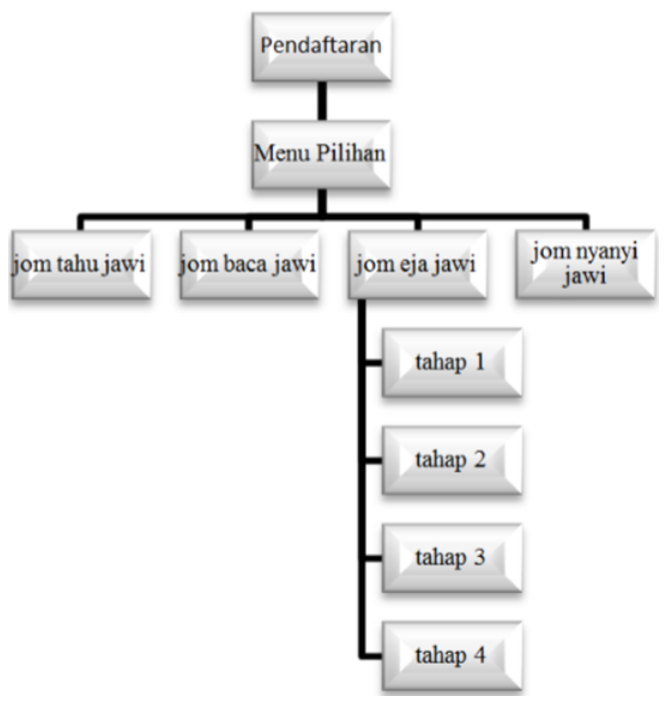

Fig. 1. Flow Chart of the Mobile Apps 
Figure 1 shows the flowchart of the process of the 'Oh Jawiku' app developed. This application is simple and consists of just a few pages with clear visual content so that students can easily browse and use this app without any help. There are four levels of the game in the 'jom eja Jawi' section designed according to the syllabus of Jawi year two primary schools.
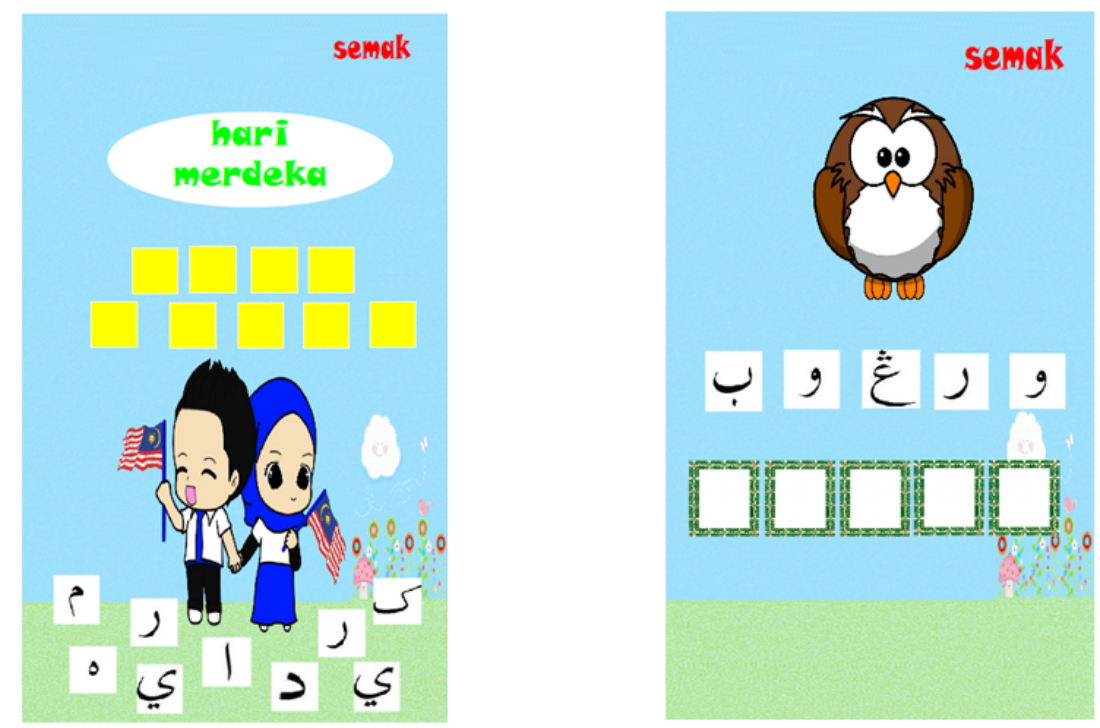

Fig. 2. Game Interfaces (Drag and Drop)

Figure 2 shows the design of drag and drop game method used for this 'Oh Jawiku' app is one of the puzzle game approaches where constructivism theory is implemented when undergoing cognitive processes where they incorporate new information and existing information to solve all these questions. This game requires students to answer questions by compiling the Jawi letters to be the desired word. Students need to complete the entire answers box with the correct answer. If a student chooses a wrong answer, the student cannot fill the answer box. This concept can train cognitivism and creativity of the students to solve every question given.

\subsection{Development phase}

'Oh Jawiku' app development uses Adobe Flash CS 5.5 software and AIR for Android player as a platform to play 'Oh Jawiku' app by Android platform. Therefore, students must download Adobe AIR software before downloading the 'Oh Jawiku' app. Besides that, ActionScript 3.0 has been used to develop this 'Oh Jawiku' app and choose a screen size of $480 \times 800$ pixels. 


\subsection{Implementation phase}

Through this phase, the experiments are conducted on the selected respondents at the beginning of the study. Respondents are likely to use the mobile app and every respondent response will be taken into account for the purpose of upgrading. The implementation Phase of this study was done during the Pilot study.

\subsection{Evaluation phase}

This study used pre-experimental research design one group pre-test and post-test to identify the effectiveness of Jawi spelling skills app developed. The study was conducted among 20 students of a primary school. The selected students are from the first class in the school and get the grade A in the subject of Islamic education during the final year examinations in 2016. The criteria for respondent selection are to ensure that all respondents are able to control the application developed and able to read, write, and spell using Jawi script.

The pre-test will be answered by the student before they expose to the 'Oh Jawiku' mobile applications. This pre-test is to measure the ability of students towards Jawi spelling skills. After that, the researcher will test the 'Oh Jawiku' mobile applications to the students and the students will be answering the post-test questions. Table 1 explains the one group experimental research design that used in this research.

Table 1. One Group Experimental Research Design

\begin{tabular}{|c|c|c|c|}
\hline Group & Pre-test & Treatment & Post-test \\
\hline Treatment & $\mathrm{T} 1$ & $\mathrm{X}$ & $\mathrm{T} 2$ \\
\hline
\end{tabular}

Explanation:

T1 : Pre-test before the respondents use 'Oh Jawiku' mobile applications

$\mathbf{X} \quad$ : Using 'Oh Jawiku' mobile applications

T2 : Post-test after the respondents used 'Oh Jawiku' mobile applications

Figure 3 shows the research procedure where the last step that needs to be done by the respondent is to answer a set of questionnaires aimed at getting the respondents' views of the application that has been developed before the data being analyzed. 


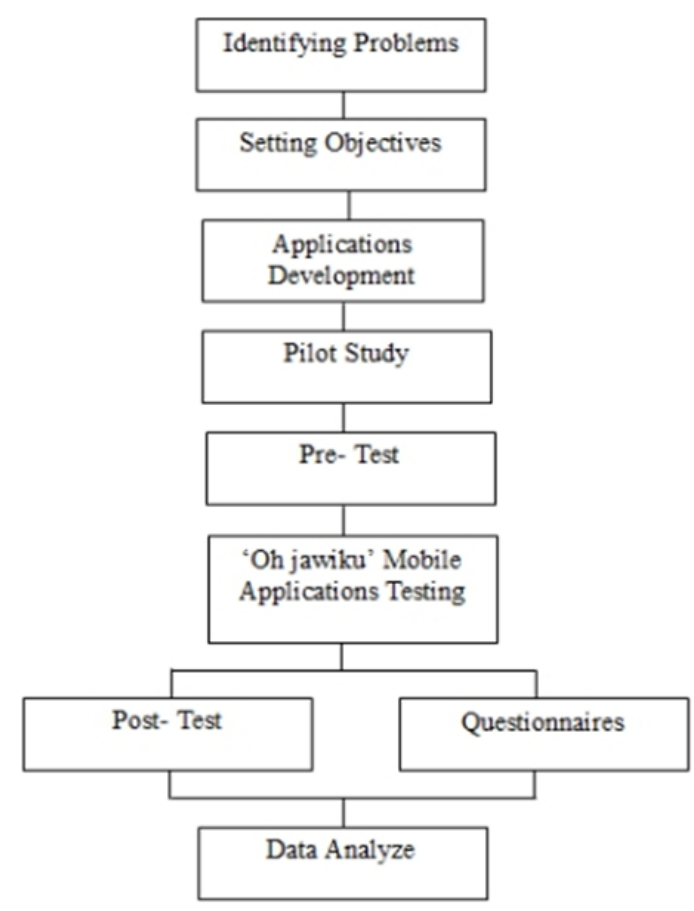

Fig. 3. Research Procedure

\section{$3 \quad$ Results}

The results of the pre-test and post-test that conducted on the respondents are as in Table 2 below.

The table shows the mean value for the pre-test is 72.25 , while the mean values for the postal exam are 89.00. This result clearly explains that the mean of post-test was higher than the mean of the pre-test. Table 3 contains the correlation of sample pairs.

Paired sample correlation values for the test scores of pre-test and post-test scores is 0.627 while the significant value is 0.003 . This proves that there is an improvement in learning process towards respondents after using the 'Oh Jawiku' mobile applications when answering test post.

Table 2. Mean and Standard Deviation of Pre-Test and Post-Test

\begin{tabular}{|l|c|c|c|}
\hline \multicolumn{1}{|c|}{ Test } & Frequency & Mean & Standard Deviation \\
\hline Pre- Test & 20 & 72.25 & 12.08 \\
\hline Post- Test & 20 & 89.00 & 11.43 \\
\hline
\end{tabular}

Table 3. Correlation of Sample Pairs

\begin{tabular}{|l|c|c|c|}
\hline & Frequency & Correlation & Sig. \\
\hline Pre-Test Score \& Post-Test Score & 20 & 0.627 & 0.003 \\
\hline
\end{tabular}


This finding is in line with the results of the study from [16] who also found that the learning method of play was more helpful to the student's cognitive power than the usual learning method.

\subsection{Students' opinion on jawi learning in the 'Oh Jawiku' mobile Apps}

Table 4 shows the findings of data collected from students' opinion on Jawi learning in the 'Oh Jawiku' mobile application.

Table 4. Students' Opinion on Jawi Learning in the 'Oh Jawiku' Mobile Application

\begin{tabular}{|c|l|c|c|}
\hline No & \multicolumn{1}{|c|}{ Items } & Yes (\%) & No (\%) \\
\hline 1 & The application is suitable to learning Jawi. & 95.00 & 5.00 \\
\hline 2 & The Jawi script used in the application is interesting. & 100.00 & 0.00 \\
\hline 3 & My knowledge about Jawi improves after using the application. & 95.00 & 5.00 \\
\hline 4 & Jawi letters easy to combine to making one word. & 100.00 & 0.00 \\
\hline 5 & Jawi spells is easy. & 95.00 & 5.00 \\
\hline 6 & I can improve my Jawi spelling skills after using this application. & 95.00 & 5.00 \\
\hline 7 & I am more interested to learn Jawi after use this application. & 85.00 & 15.00 \\
\hline 8 & This game application helps me to memorizing Jawi letters. & 100.00 & 0.00 \\
\hline 9 & I am interested to using this application for learning Jawi. & 100.00 & 0.00 \\
\hline 10 & My Jawi spelling quality will be improve by using this application. & 90.00 & 10.00 \\
\hline
\end{tabular}

Overall, data shows a selection of answers 'yes' has a higher percentage than the possible answers 'no'. This clearly shows that students' belief in the 'Oh Jawiku' application is positive and suitable for use by them. In addition, the results for the overall data show that a high percentage of the possible answers 'yes'. This means respondents from among students were satisfied with the development of 'Oh Jawiku' applications in terms of content applications and learning of Jawi in the application.

\section{Discussion}

The idea of the development of the 'Oh Jawiku' app is based on a recent study that said the younger generation today are far behind the Jawi writing that some of the students do not recognize Jawi letters due to lack of interest in Jawi writing [17]. Overall, 'Oh Jawiku' app development shows a positive effect towards student performance after using it. The mobile apps also received positive responses from the students on using it for learning Jawi Script. Students can get the beneficial activity by using this app during their leisure times. Not only getting excited, they also get a lot of knowledge and their Jawi skills will be improved day by day. The fun element applied in the 'Oh Jawiku' game app can attract students or users to continue using the app because the fun elements of a game will make the game more interesting even if it is just a simple game [12].

Hopefully, this development can benefit many students, teachers and the community in learning Jawi writing and spelling. 'Oh Jawiku' app development can help young people in cultivating an interest in studying Jawi in more depth. Hopefully, Jawi script 
will not be buried if there is more effort in restoring the glory of Jawi script such as the development of 'Oh Jawiku' mobile app.

\section{$5 \quad$ References}

[1] Ahmad Faisal Abdul Hamid and Faizuri Abdul Latif, "Sejarah Perkembangan Tulisan Jawi: Analisis Mengenai Teori Kang Kyoung Seok," J. al-Tamaddun, vol. 9, no. 2, pp. 115, 2014. https://doi.org/10.22452/jat.vo19no2.1

[2] M. A. Yusoff, "Perkembangan tulisan jawi dan aplikasinya dalam masyarakat islam di malaysia," J. Usuluddin, vol. Bil. 21, pp. 23-38, 2005.

[3] A. Hashim, "Pemerkasaan Kembali Tulisan Jawi," J. Aswara, pp. 159-175, 2009.

[4] Nur Azuki Yusuff and Nik Yusri Musa, "Penerimaan dan Halatuju Tulisan Jawi; Suatu Tinjauan dari Pandangan Remaja Kini,” p. 11, 2010.

[5] Mardhiyyah, "Penggunaan Kaedah Tiru Macam Saya Membantu Menyambung Huruf Jawi Tunggal Dalam Kalangan Murid Tahun 3," Koleks. Artik. Penyelid. Tindakan PISMP Pendidik. Islam amb. Januari 2009, Semin. Penyelid. Tindakan IPG KBL Tahun 2012, ms 89-100., vol. 53, no. September, p. 160, 2009.

[6] Naquiah Nahar and Jimaain Safar, "Pengajaran Jawi Berkesan Dalam Usaha Memartabatkan Warisan Budaya Bangsa,” Proceeding Int. Conf. Educ. Towar. Glob. Peace, no. November, pp. 1-17, 2016.

[7] F. Mayra, "Mobile Games,” Int. Encycl. Digit. Commun. Soc., pp. 1-6, 2015.

[8] M. J. Ferreira, F. Moreira, C. S. Pereira, and N. Durão, “The Role of Mobile Technologies in the Teaching / Learning Process Improvement in Portugal," 8th Annu. Int. Conf. Educ. Res. Innov. (ICERI 2015), no. 16th-18th November 2015, pp. 4600-4610, 2015.

[9] E. Vazquez-Cano, "Mobile Distance Learning with Smartphones and Apps in Higher Education," Educ. Sci. Theory Pract., vol. 14, no. 4, pp. 1505-1520, 2014.

[10] Nur Syamira et.al, "Kefahaman Al-Quran dan Jawi Melalui Permainan Bahasa Bermultimedia," ASEAN Comp. Educ. Res. J. Islam Civiliz. Vol. 1(1) January 2017, 41-53., vol. 1, no. January, pp. 41-53, 2017.

[11] Adly dan Mardzelah, "Kesan Play-Based Learning terhadap Afektif Murid Pemulihan Jawi J-QAF di Sekolah Rendah,” Proceeding of ICERS, vol. 1, no. October, pp. 587-598, 2016. https://doi.org/10.21070/picecrs.v1i1.530

[12] M. Prensky, "Fun, Play and Games : What Makes Games Engaging," Digit. Game-Based Learn., pp. 1-31, 2001.

[13] A. L. Thomas, "Digital game-based textbook vs. traditional print-based textbook: The effect of textbook format on college students' engagement with textbook content outside of the classroom," Turkish Online J. Educ. Technol., vol. 16, no. 4, pp. 12-18, 2017.

[14] S. Juniu, "Use of Technology for Constructivist Learning in a Performance Assessment Class," vol. 10, no. 1, pp. 67-78, 2006.

[15] J. Wongta, “A Development of Augmented Reality- supported Mobile Game Application based on Jolly Phonics Approach to Enhancing English Phonics Learning Performance of ESL Learners," no. November 2016, 2018. https://doi.org/10.1109/ic3.2018.000-7

[16] S. R. Dehkordi, "Using Mobile Game Application to Teach Children with Autism Spectrum Disorder ( ASD ) Multiple Cues Responding : A Pilot Study," no. September, pp. 10 15, 2014. https://doi.org/10.1109/iuser.2014.7002705

[17] N. Rosila and N. Yaacob, "Penguasaan Jawi Dan Hubungannya Dengan Minat," Pendidik dan Pendidik., vol. Jil. 22, pp. 161-172, 2007. 


\section{Authors}

Noor Asmina Binti Mohd Rashid, Shaharuddin Bin Md Salleh and Norah Binti Md Noor are with Universiti Teknologi Malaysia, Johor, Malaysia.

Article submitted 2019-03-23. Resubmitted 2019-05-17. Final acceptance 2019-06-10. Final version published as submitted by the authors 